\title{
F11R Gene
}

National Cancer Institute

\section{Source}

National Cancer Institute. F11R Gene. NCI Thesaurus. Code C118591.

This gene is involved in the formation of cell-cell junctions. 